\title{
DENSITY, AMOUNT, AND CARBON CONTENT OF ORGANIC MATTER IN SOILS - SOME METHODICAL REFLECTIONS
}

\author{
Reijo Heinonen \\ Department of Agricultural Chemistry, University of Helsinki
}

Received April 19th, 1960.

The author has shown previously (4) that the density of mineral topsoils in southern Finland $(\mathrm{Y})$ can be calculated from the equation

$$
\mathrm{Y}=2.697+0.0007 \mathrm{x}_{1}-0.0265 \mathrm{x}_{2}
$$

where $x_{1}$ and $x_{2}$ are the percentages of clay and organic matter, respectively. The material consisted of 94 samples of varying texture and organic matter content but of uniform geological origin (glacial sediments). The clay content ranged from 12 to 75 per cent, and the organic matter content from 2 to 12 per cent, the averages being 37 and 6.08 per cent, respectively. There was only a rather weak correlation between these factors; correlation coefficient $\mathrm{r}=0.40$.

The density of soil organic matter can be derived from equation (1) as follows (6). If the densities of total soil solids, soil minerals and soil organic matter are $\varrho_{\mathrm{s}}, \varrho_{\mathrm{m}}$ and $\varrho_{0}$ and the respective masses of these quantities are $\mathrm{W}_{\mathrm{s}}, \mathrm{W}_{\mathrm{m}}$ and $\mathrm{W}_{0}$, the volume relaticnships are:

$$
\frac{\mathrm{W}_{0}}{\varrho_{0}}+\frac{\mathrm{W}_{\mathrm{s}}}{\varrho_{\mathrm{s}}}=\frac{\mathrm{W}_{\mathrm{m}}}{\varrho_{\mathrm{m}}}
$$

By substituting in equation (2) the respective mean values from the investigated material and the average density of the mineral constituent, which can be calculated with sufficient accuracy on the basis of the average clay content (4), one finds

$$
\frac{6.08}{\varrho_{0}}+\frac{93.92}{2.723}=\frac{100}{2.562}, \text { and hence } \varrho_{0}=1.34
$$


It seems that, disregarding the effect of the clay content, the soil density might be approximately calculated for members of a more extensive series comprising also organic soils, by assuming the values 2.75 and 1.25 for the densities of mineral matter and organic matter (4). In comparison with many of the values reported in the literature, a density of about 1.3 for the organic matter in soil is in no way exceptional; but reference to the thorough investigations of SMith (6) and SEgEBERG (5) indicate that this figure may be too low for the average of a fairly large series. The first-mentioned author found for the organic matter in the A horizon the average value of 1.54, the latter correspondingly for an extensive German peatland material the value 1.45. This led the present author to study the basis of the method which was employed; although the result was derived in an indirect way, it should be very nearly correct in a series of this extent unless there are systematic errors in the method.

The density was determined with the aid of $50 \mathrm{ml}$ measuring flasks and alcohol, but this rapid method was carefully calibrated so that it produced results identical with those obtained by the classical pyknometer method with water as medium (3). The organic carbon was determined using a Walkley-Black type digestion and colorimetry, and the organic matter was calculated with the coefficient 1.72 . By the inclusion of standard soil in each batch, this method was calibrated to produce a result identical with that derived by digestion in the water-bath $(1,3)$. However, an accurate combustion performed later on the standard soil showed that the total quantity of organic carbon was 9.5 per cent higher than the value obtained by digestion in the water-bath. As also the coefficient 1.72 is obviously too small (2), the calculated organic matter contents are too low by an estimated 20 per cent despite their consistency with general practice.

If the total organic carbon quantity is used for $x_{2}$ in equation (1) instead of the organic matter, the equation obtains the following form:

$$
\mathrm{Y}=2.697+0.0007 \mathrm{x}_{1}-0.0416 \mathrm{x}_{2}
$$

When the organic matter in the soil is calculated from the total organic carbon by the coefficient $1.9(2)$, the average organic matter percentage of the investigated series will be 7.36 instead of 6.08 . If this is substituted in equation (2), the value 1.47 , instead of 1.34 , is obtained for the density of the organic matter. This appears more appropriate in the light of other investigations.

Results of investigations derived from entirely different sources have thus proved to be well compatible. This indicates that there are no systematic errors in the methods and calculations involved, or that they are negligible.

\section{$S u m m a r y$}

The density of soil organic matter has been derived from an equation representing the regression of soil density on the clay and organic matter contents. When the amount of organic matter was taken as equalling 1.9 times the total organic 
carbon, this resulted in the value 1.47 for the density of soil organic matter, which is believed to be an appropriate figure.

Acknowledgemint: Thanks are due to Dr. K. Valdmaa, Royal Agr. Coll., Sweden, for the determination of the total organic carbon content of the sstandard soilsby the dry and wet combustion methods, as well as for a helpful discussion of the problern.

\section{R E F E R E N C E S}

(1) Alten, F. \& Wandrowsky, B. \& Knippenberg, E. 1935. Beitrag zur Humusbestimmung. Erg. Agrikulturchemie 4:61-69.

(2) Broadbent, F. F.. 1953. The soil organic fraction. Adv. Agron. 5: 153-183.

(3) Heinonen, R. 1954. Multakerroksen kosteussuhteista Suomen maalajeissa. Summary: Moisture conditiors in Finnish topsoils. Agrogeol. julk. 62: 1-82.

(4) - 1957. Suomen maalajien ominaispainosta. Summary: On the specific gravity in Finnish soils. J. Sci. Agr. Soc. Finland 29:38-40.

(5) Segeberg, H. 1955. Zur Kenntnis der spezifischen Gewichte von Niedermoortorfen. Z. Pfl.ern. Düng. Fodenk. 71: 133-141.

(6) Sмгтн, W. O. 19.43. Density of soil solids and their genetic relations. Soil Sci. 56: $263-272$.

S E L O T U S :

MAAN ORGAANISEN AINEKSEN OMINAISPAINO, MÅ̊R J JA HIILIPITOISUUSTUTKIMUSTULOSTEN JA METODIEN TARKASTELUA

REIJO HEINONEN

Maanviljelyskemian laitos, Helsingin yliopisto

Kun orgaanisen aineksen ominaispaino laskettiin nojautuen regressioyhtälöön, joka osoittaa maan ominaispainon tekstuurin ja shumuspitoisuudens funktiona, saatiin ilmeisesti liian pieni arvo 1.34. Tämä näyttäă johtuvan siitä, että käytetty yleinen humuspitoisuuden määritys- ja laskutapa (1.72 $\times$ org. C, Altevin men€ telmää vastaava määritys) antaa n. $20 \%$ liian alhaisia tuloksia, mistä virheestä puolet johtuu epätäydellisestä palamisesta ja puolet liian alhaisesta kertoimesta.

Kun orgaanisen aineksen määrä sitten laskettiin hiilipitoisuudesta BROADBENrin suosittelemalla kertoimella 1.9 ja pidettiin perustana vertailunäytteen orgaanisen hilien totaalimäärää, saatiin humuksen keskimääräiseksi ominaispainoksi 1.47, mikä muiden tutkimusten valossa näyttää oikeaan osuvalta. Eri lähteistä saadut tiedot osoittautuvat täten yhteensoveltuviksi, mikä viittaa siihen, että määritysmenetelmissł̇i ja nyt käytetyissä laskuperusteissa ei ole mainittavia systemaattisia virheitä. 